\title{
PENGARUH WORD OF MOUTH TERHADAP PURCHASE INTENTION MELALUI BRAND IMAGE PADA LEMBAGA KURSUS BAHASA INGGRIS DYNAMIC ENGLISH COURSE PARE
}

\author{
M. Dian Ruhamak \\ Fakultas Ekonomi Universitas Kadiri-Kediri \\ dianru@unik-kediri.ac.id \\ Budi Rahayu \\ Fakultas Ekonomi Universitas Kadiri \\ budirahayu16041958@gmail.com
}

\begin{abstract}
Abstrak
Penelitian ini bertujuan mengetahui seberapa besar pengaruh Word Of Mouth terhadap Purchase Intention melalui Brand Image pada lembaga kursus bahasa inggris Dynamic English Course Pare - Kediri. Penelitian ini menggunakan metode SEM PLS dengan bantuan software SmartPLS didapatkan hasil signifikansi pengaruh Word Of Mouth terhadap Brand Image, Word Of Mouth Terhadap Purchase Intention, Brand Image terhadap Purchase Intention dan Word Of Mouth Terhadap Purchase Intention melalui Brand Image sebesar $24,3 \%, 65,3 \%, 33,6 \%$ dan 46,4\%. Dengan demikian semua dinyatakan signifikan karena semua mempengaruhi Purchase Intention dan Brand Image memediasi sempurna Word Of Mouth dengan Purchase Intention karena dapat meningkatkan pengaruh sebesar $21,9 \%$.
\end{abstract}

Kata kunci: Word Of Mouth, Brand Image, Purchase Intention

\section{PENDAHULUAN}

\section{Latar Belakang}

Bahasa merupakan salah satu alat komunikasi yang sangat penting dan selalu digunakan dalam masyarakat. ada berbagai bahasa yang digunakan dalam komunikasi, salah satunya bahasa inggris. Dalam dunia pendidikan bahasa inggris adalah bahasa yang paling menonjol dan hampir pasti dipelajari bahkan sejak sekolah dasar.

Di kota Pare banyak sekali terdapat lembaga kursus bahasa inggris dan banyak sekali peminat yang datang ke kota pare hanya untuk menamba kemampuan berbahasa inggris dengan lancar dan baik. Tidak hanya dari dalam kota saja yang datang, bahkan dari luar pulau jawa dalam setahun sekali atau dua kali pasti ada rombongan yang datang.

Banyak sekolah yang mengisi liburan mulai sd, smp, sma bahkan mahasiswa yang datang ke kampung inggris untuk menimba ilmu disana. Mereka memanfaatkan waktu liburan untuk berkursus demi kelancaran dalam berbicara menggunakan bahasa inggris. seiring berjalannya waktu banyak bermunculan lembaga kursus baru yang menawarkan paket kursus bahasa inggris dengan harga dan fasilitas yang menarik. DEC sebagai salah satu lembaga kursus yang cukup lama berdiri di kota pare, bahkan sudah memiliki kantor 
cabang di luar daerah. Dengan tentor yang berpengalaman dan metode pengajaran yang menyenangkan serta tempat belajar yang memadai menjadikan magnet tersendiri untuk menarik konsumen dalam menjadikan DEC sebagai pilihan untuk menimba ilmu. Namun dengan semakin banyak lembaga yang berdiri DEC harus mempunyai strategi dalam menarik minat konsumen agar tidak kalah dengan lembaga lain sejenis.

\section{Rumusan Masalah}
a. Apakah Word Of Mouth berpengaruh signifikan Terhadap Brand Image
b. Apakah Word Of Mouth berpengaruh signifikan Terhadap Purchase Intention
c. Apakah Brand Image berpengaruh signifikan Terhadap Purchase Intention
d. Apakah Word Of Mouth berpengaruh signifikan Terhadap Purchase Intention melalui Brand Image

\section{Tujuan}

a. Untuk mengetahui pengaruh WOM terhadap Purchase Intention DEC Pare

b. Untuk mengetahui pengaruh WOM terhadap Brand Image DEC Pare

c. Untuk mengetahui pengaruh Brand Image terhadap Purchase Intention DEC Pare

d. Untuk mengetahui pengaruh WOM terhadap Purchase Intention Melalui Brand Image pada DEC Pare

\section{Batasan Masalah}

Karena di kota Pare banyak sekali terdapat lembaga kursus maka peneliti memberi batasan penelitian hanya pada lembaga kursus DEC saja karena pertimbangan kemudahan akses lokasi dan DEC salah satu lembaga yang telah cukup lama berdiri di kota pare.

\section{TINJAUAN PUSTAKA}

\section{Penelitian terdahulu}

Dana Fitriana dan Ida Yulianti JIM FEB UB Malang Vol. 2 No. 2 Tahun 2013 "Pengaruh Brand Image Terhadap Purchase Intention Pada Produk Otomotif (Studi Kasus Pada Calon Pembeli Toyota Avanza Di Auto 2000 Sutoyo- Malang )". Hasil penelitian menunjukkan bahwa secara simultan dimensi functional image, affective image, reputation image berpengaruh secara signifikan terhadap purchase intention dengan signifikansi 0,000 dengan koefisiensi determinasi (R2) sebesar 0,517 atau 51,7\%.

M. Yudha Ghozali dan Tommy Setiawan Ruslim. Fakultas Ekonomi Universitas Tarumanegara, Jakarta, Indonesia. Tahun 2015 "Efek E-WOM terhadap Brand image dan Purchase Intention (Studi Kasus Pada Industri Mobil “D”)". Penelitian ini merekomendasikan variabel brand image sbagai variabel intervening yang memperkuat pengaruh eWOM terhadap purchase intention. Hal ini dapat dijelaskan bahwa konsumen yang memberikan rekomendasi terhadap suatu produk akan memperkuat citra merek produk tersebut dan citra merek ini yang memperkuat rekomendasi konsumen agar intensi pembelian meningkat. 


\section{Jasa}

Jasa menurut Kotler (2003) adalah setiap tindakan atau aktivitas yang dapat ditawarkan suatu pihak kepada pihak lain, yang bersifat intangible (tidak berwujud) dan tidak menghasilkan kepemilikan sesuatu. Produksi jasa bias dihubungkan dengan produk fisik maupun tidak.

Jasa, dengan beberapa karakteritik-nya, yaitu (Lovelock, 2001): intangibility (tidak dapat dilihat, dirasa, diraba, dicium atau didengar sebelum dibeli), heterogeneity (sifat jasa yang heterogen/variatif menyebabkansulit distandardisasi), perishability of output (tidak dapat dibentuk persediaan), dan simultaneity of production and consumption or inseparability (proses operasi bersamaan dengan proses konsumsi), menyebabkan pemasaran jasa lebih kompleks dan lebih sulit dari pemasaran barang.

Pengguna jasa memiliki preferensi dan persepsi sendiri dalam menilai performance dari jasa perusahaan yang mereka konsumsi, dan hal yang lebih penting untuk diperhatikan oleh pemberi jasa adalah bahwa mereka biasanya akan menceritakan pengalamannya atas jasa yang dikonsumsi, baik yang sifatnya positif maupun negatif kepada pihak lain melalui kegiatan 'word-of-mouth communication'.

\section{Word Of Mouth}

Ronny dan Chie Jeffry Sunandar (2007) komunikasi dari mulut ke mulut (word of mouth communication) dapat diukur dengan indikator sebagai berikut: Kemauan pelanggan dalam membicarakan hal-hal positif kualitas pelayanan perusahaan kepada orang lain,rekomendasi jasa perusahaan kepada orang lain, dorongan terhadap teman/relasi untuk melakukan pembelian terhadap jasa perusahaan.

Word-of-mouth communication, pada dasarnya adalah pesan tentang produk atau jasa suatu perusahaan, ataupun tentang perusahaan itu sendiri, dalam bentuk komentar tentang kinerja produk, keramahan, kejujuran, kecepatan pelayanan dan hal lainnya yang dirasakan dan dialami oleh seseorang yang disampaikan kepada orang lain. Pesan yang disampaikan dapat berbentuk pesan yang sifatnya positif maupun negatif bergantung pada apa yang dirasakan oleh si pemberi pesan tersebut atas jasa yang ia konsumsi.

Dalam penelitian ini kontstruk perilaku WOM mengacu pada konsep Swan \& Oliver (dalam Chew \& Jochen, 2001), yaitu: "the likelihood to generate word-of-mouth, the favorability of word-of-mouth generated, and likelihood to make a purchase recommendation.

Perilaku WOM dapat dihubungkan dengan kepuasan dan ketidakpuasan konsumen dengan pengalaman konsumsinya terdahulu (Blodget, 1993; Brown \& Beltramini 1989, dan lain-lain). Kepuasan konsumen oleh Kotler didefinisikan sebagai berikut: "satisfaction is a person's feeling of pleasure or disappointment resulting from comparing a product's perceived performance (or outcome) in relation to his or her expectations. If the performance fall short of expectations, the customer is dissatisfied. If the performance matches the expectations, the customer is satisfied. If the performance exceeds expectations, the customer is highly satisfied or delighted".

Dalam kaitannya dengan word of mouth, Kotler \& Keller (2008:6), menyatakan bahwa saluran komunikasi personal dalam ucapan atau perkataan dari mulut ke mulut (Word 
of Mouth) bisa menjadi metode promosi yang efektif karena pada umumnya disampaikan dari konsumen oleh konsumen dan untuk konsumen, sehingga konsumen yang puas dapat menjadi media iklan bagi perusahaan. kemudian Tsoukatos dan Rand (dalam Norizan Kassim \& Nor Asiah Abdullah (2010), berargumen bahwa strategi defensive dapat lebih menguntungkan melalui peningkatan cross selling, mungkin pada harga yang lebih tinggi, dan kata positif dari komunikasi WOM yang bersifat mengajak. Menurut Hasan (2013:133) Word of Mouth merupakan upaya mengantarkan dan menyampaikan pesan bisnis kepada orang lain, keluarga, teman dan rekan bisnis. Selain itu, Hasan (2013:93) menuturkan bahwa konsumen yang percaya pada penyedia jasa atau terlibat dalam proses pembelian cenderung untuk berpartisipasi dalam rekomendasi mulut ke mulut (Word of Mouth) dan pembelaan terhadap penyedia jasa sebagai bagian dari keinginan untuk meningkatkan keinginan untuk meningkatkan komitmen mereka.

\section{Pengertian Purchase Intention}

Definisi Purchase Intention menurut Fishbein dan Ajsen yang dikutip dari Lin dan Lin (2007) adalah "purchase intention means a subjective inclination consumers have towards a certain product, and has been proven to be a key factor to predict consumer behaviour." Menurut Engel, Kollat, dan Blackwell yang dikutip dari Lin dan Lin (2007) Purchase Intention adalah "process used to evaluate consumer decision making". Sedangkan menurut Kotler (2000) definisi Purchase Intention adalah "consumer behaviour occur when consumer stimulated by external factors and cometo purchase decision based their personal chacacteristics and decision making process".

Purchase Intention adalah sesuatu hal yang mewakili konsumen yang mempunyai kemungkinan, akan, rencana atau bersedia untuk membeli suatu produk atau layanan di masa depan. Peningkatan niat pembelian ini berarti peningkatan kemungkinan pembelian (Dodds Et Al,1991; Schiffman dan Kanuk, 2007). Para peneliti juga bisa menggunakan niat membeli sebagai indikator penting untuk memperkirakan perilaku konsumen. Ketika konsumen telah mempunyai niat untuk membeli yang positif ini bentuk komitmen pada sebuah merek, bahwa merek itu positif dan baik. Hal tersebutlah yang mendorong pembelian yang pada akhirnya akan dilakukan oleh konsumen (Fishbein dan Ajzen, tahun 1975; Schiffman dan Kanuk, 2007). Purchase intention atau minat beli menurut Assael (1998) merupakan kecenderungan konsumen untuk membeli suatu merek atau mengambil tindakan yang berhubungan dengan pembelian yang diukur dengan tingkat kemungkinan konsumen melakukan pembelian. Pengertian minat beli menurut Howard (1994) adalah sesuatu yang berhubungan dengan rencana konsumen untuk membeli produk tertentu serta berapa banyak unit produk yang dibutuhkan pada periode tertentu. Dapat dikatakan bahwa minat beli merupakan pernyataan mental dari konsumen yang merefleksikan rencana pembelian sejumlah produk dengan merek tertentu. Hal ini sangat diperlukan oleh para pemasar untuk mengetahui minat beli konsumen terhadap suatu produk, baik pemasar maupun ahli ekonomi menggunakan variabel minat untuk memprediksi perilaku konsumen di masa yang akan datang.

Niat beli dapat didefinisikan sebagai niat seseorang untuk membeli merek tertentu yang telah mereka pilih untuk diri mereka sendiri setelah mengevaluasi. Variabel ini bisa diukur misalnya dengan mempertimbangkan merek untuk pembelian dan mengharapkan untuk membeli produk tersebut dimasa yang akan datang (Laroche dan Zhou dalam Khan 
dkk. (2012). Halim dan Hameed (2005) dalam Tariq dkk. (2013), menjelaskan bahwa, niat beli sebagai jumlah pelanggan yang memiliki usulan untuk membeli produk di masa depan dan melakukan pembelian pengulangan dan berhubungan pada produk tertentu dalam jangka waktu yang lama. In \& Kang dalam Tariq dkk. (2013), menjelaskan bahwa niat pembelian berkaitan dengan empat perilaku konsumen, seperti: rencana yang ragu untuk membeli sebuah produk, secara tegas untuk membeli produk, berfikir untuk membeli produk di masa depan dan membeli produk tertentu di masa depan, sehingga bisa saja tidak terburu-buru memutuskan berbelanja dalam jangka waktu yang lama.

Model AIDA merupakan unsur dari purchase intention seperti yang dijelaskan oleh Kotler (2000). Model AIDA terdiri dari :

a. Attention

Keterkaitan konsumen dan produk, dalam hal ini di mana perusahaan dapat menaruh perhatian konsumen dengan melakukan pendekatan agar konsumen menyadari keberadaan produk dan kualitasnya.

b. Interest

Kepekaan konsumen terhadap produk, dalam tahap ini konsumen ditumbuhkan dan diciptakan rasa ketertarikan terhadap produk tersebut. Perusahaan berusaha agar produknya mempunyai daya tarik dalam diri konsumen, sehingga konsumen memiliki rasa ingin tahu yang dapat menimbulkan minatnya terhadap suatu produk.

c. Desire

Keinginan konsumen untuk mencoba dan memiliki produk tersebut, rasa ingin tahu konsumen terhadap produk tersebut diarahkan kepada minat untuk membeli.

d. Action

Tindakan konsumen untuk mengambil keputusan melakukan pembelian.

Menurut Setiadi (2003), proses pembelian secara spesifik terdiri atas urutan kejadian berikut: Pengenalan masalah kebutuhan, pencarian informasi, evaluasi alternatif, keputusan pembelian, dan perilaku pasca pembelian.

\section{Brand Image}

Brand image atau brand description, yakni deskripsi tentang asosiasi dan keyakinan konsumen terhadap merek tertentu (Tjiptono, 2005 : 49). Menurut Kotler, brand image adalah sejumlah keyakinan tentang merek. Menurut Aaker, brand image dianggap sebagai "bagaimana merek dipersepsikan oleh konsumen". Berkenaan dengan persepsi, menurut Davis, seperti halnya manusia, merek juga bisa digambarkan melalui kata sifat (adjective), kata keterangan (adverb), atau frase (phrase). Davis juga mengatakan bahwa brand image memiliki dua komponen, yaitu asosiasi merek dan brand personal. (Simamora, 2003: 63).

Menurut Kotler (2007 : 346) citra merek ialah persepsi dan keyakinan yang dilakukan oleh konsumen, seperti tercermin dalam asosiasi yang terjadi dalam memori konsumen. Menurut Nugroho (2003 : 182) menyatakan bahwa image atau citra adalah realitas, oleh karena itu jika komunikasi pasar tidak cocok dengan realitas, secara normal realitas akan 
menang. Citra akhirnya akan menjadi baik, ketika konsumen mempunyai pengalaman yang cukup dengan realitas baru. Realitas baru yang dimaksud yaitu bahwa sebenarnya organisasi bekerja lebih efektif dan mempunyai kinerja yang baik.

Kotler (2002 : 215) mendefinisikan citra merek sebagai seperangkat keyakinan, ide, dan kesan yang dimiliki oleh seseorang terhadap suatu merek. Karena itu sikap dan tindakan konsumen terhadap suatu merek sangat ditentukan oleh citra merek tersebut. Kotler (2002 : 225) juga menambahkan bahwa citra merek merupakan syarat dari merek yang kuat dan citra adalah persepsi yang relatif konsisten dalam jangka panjang (enduring perception). Jadi tidak mudah untuk membentuk citra, sehingga bila terbentuk akan sulit untuk mengubahnya.

Citra yang dibentuk harus jelas dan memiliki keunggulan bila dibandingkan dengan pesaingnya. Saat perbedaan dan keunggulan merek dihadapkan dengan merek lain, munculah posisi merek. Jadi, pada dasarnya sama dengan proses persepsi, karena citra terbentuk dari persepsi yang telah terbentuk lama. Setelah melalui tahap yang terjadi dalam proses persepsi, kemudian dilanjutkan pada tahap keterlibatan konsumen. Level keterlibatan ini selain mempengaruhi persepsi juga mempengaruhi fungsi memori.

Berdasarkan pendapat di atas Hapsari (2007) mengambil beberapa kesimpulan tentang brand image sebagai berikut:

a. Brand image merupakan pemahaman konsumen mengenai merek secara keseluruhan. kepercayaan konsumen terhadap merek dan bagaimana pandangan konsumen tentang merek.

b. Brand image tidak semata ditentukan oleh bagaimana pemberian nama yang baik kepada sebuah produk. tetapi juga dibutuhkan bagaimana cara memperkenalkan produk tersebut agar dapat menjadi sebuah memori bagi konsumen dalam membentuk suatu persepsi akan sebuah produk.

c. Brand image sangat berpatokan pada pemahaman, kepercayaan, dan pandangan atau persepsi konsumen terhadap suatu merek.

d. Brand image dapat dianggap jenis asosiasi yang muncul di benak konsumen ketika mengingat sebuah merek tertentu. Asosiasi tersebut secara sederhana dapat muncul dalam bentuk pemikiran atau citra tertentu yang dikaitkan pada suatu merek.

e. Brand image sangat berpatokan pada pemahaman, kepercayaan, dan pandangan atau persepsi konsumen terhadap suatu merek.

f. Brand image dapat dianggap jenis asosiasi yang muncul di benak konsumen ketika mengingat sebuah merek tertentu. Asosiasi tersebut secara sederhana dapat muncul dalam bentuk pemikiran atau citra tertentu yang dikaitkan pada suatu merek.

g. Brand image yang positif akan membuat konsumen menyukai suatu produk dengan merek yang bersangkutan di kemudian hari, sedangkan bagi produsen brand image yang baik akan menghambat kegiatan pemasaran pesaing.

h. Brand image merupakan faktor yang penting yang dapat membuat konsumen mengeluarkan keputusan untuk mengkonsumsi bahkan sampai kepada tahap loyalitas di dalam menggunakan suatu merek produk tertentu, karena brand image mempengaruhi hubungan emosional antara konsumen dengan suatu merek, sehingga merek yang 
penawarannya sesuai dengan kebutuhan akan terpilih untuk dikonsumsi.

Citra merek adalah persepsi atau kesan tentang suatu merek yang direfleksikan oleh sekumpulan asosiasi yang menghubungkan pelanggan dengan merek dalam ingatannya menurut Keller dalam Sitinjak, (2005). Menurut Temporal (2002) dalam Sitinjak (2005) citra dapat didasarkan kepada kenyataan atau fiksi tergantung bagaimana konsumen mempersepsi. Citra merek memiliki dua komponen yaitu asosiasi merek (brand assosiation) dan "pesona" merek (brand "pesona"), asosiasi merek membantu memahami manfaat merek yang diterima konsumen dan "pesona" merek adalah deskripsi dari merek dalam konteks karakteristik manuasia, sehingga hal ini membantu konsumen dalam memahami kekuatan dan kelemahan merek.

Shimp (2003) berpendapat bahwa citra merek (brand image) dapat dianggap sebagai jenis asosiasi yang muncul di benak konsumen ketika mengingat sebuah merek tertentu, asosiasi tersebut secara sederhana dapat muncul dalam bentuk pemikiran atau citra tertentu yang dikaitkan kepada suatu merek, sama halnya ketika berfikir tentang orang lain. Berdasarkan pendapat tersebut diatas, maka dapat disimpulkan bahwa citra merek dapat positif maupun negatif di dalam benak seseorang, tergantung pada persepsi masing-masing orang terhadap merek itu sendiri.

Menurut Aaker dikutip oleh Simamora (2002) dalam Sitinjak (2005) bahwa citra merek adalah seperangkat asosiasi yang ingin diciptakan atau dipelihara oleh pemasar. Asosiasi-asosiasi itu menyatakan apa sesungguhnya merek dan apa yang dijanjikan kepada konsumen. Merek merupakan symbol dan indikator dari kualitas sebuah produk. Oleh karena itu, merek-merek produk yang sudah lama akan menjadi sebuah citra bahkan simbol status bagi produk tersebut yang mampu meningkatkan citra pemakainya, komponen citra merek terdiri atas 3 bagian, yaitu:

a. Citra Pembuat yaitu, sekumpulan asosiasi yang dipersepsikan konsumen terhadap perusahaan yang membuat suatu barang dan jasa.

b. Citra pemakai yaitu, sekumpulan asosiasi yang dipersepsikan konsumen terhadap pemakai yang menggunakan suatu barang dan jasa.

c. Citra produk yaitu, sekumpulan asosiasi yang dipersepsikan konsumen terhadap suatu barang dan jasa.

Menurut Schicffinan dan Kanuk (1997) dalam Sitinjak (2005) faktor - factor pembentuk citra merek adalah sebagai berikut:

a. Kualitas atau mutu, berkaitan dengan kualitas produk barang yang ditawarkan oleh produsen dengan merek tertentu.

b. Dapat dipercaya atau diandalkan, berkaitan dengan pendapat atau kesepakatan yang dibentuk oleh masyarakat tentang suatu produk yang dikonsumsi.

c. Kegunaan atau manfaat, yang berkaitan dengan fungsi dari suatau produk barang yang bisa dimanfaatkan oleh konsumen.

d. Pelayanan yang berkaitan dengan tugas produsen dalam melayani konsumennya.

e. Resiko, berkaitan dengan besar kecilnya akibat atau untung dan rugi yang mungkin dialami oleh konsumen. 


\section{Kerangka Berpikir}

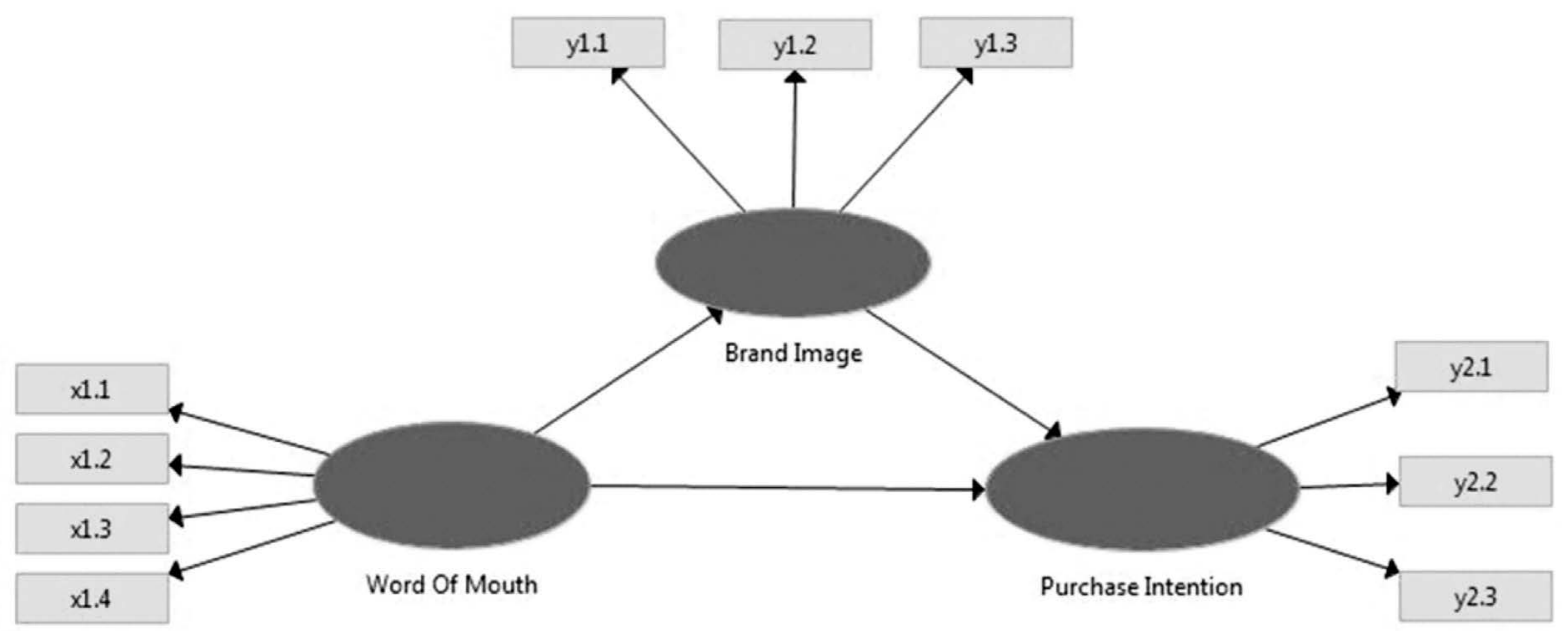

\section{Hipotesis}

H1 : Word Of Mouth berpengaruh signifikan Terhadap Brand Image

H2 : Word Of Mouth berpengaruh signifikan Terhadap Purchase Intention

H3 : Brand Image berpengaruh signifikan Terhadap Purchase Intention

H4 : Word Of Mouth berpengaruh signifikan Terhadap Purchase Intention melalui Brand Image

\section{METODE PENELITIAN}

\section{Jenis Penelitian}

Jenis penelitian yang digunakan dalam penelitian ini adalah eksplanatory research. Eksplanatory research ini ditujukan untuk mengetahui besar kecilnya pengaruh antara variabel independen dengan variable dependen.

\section{Populasi dan Sampel}

Populasi adalah gabungan dari seluruh elemen yang berbentuk peristiwa, hal atau orang yang memiliki karakteristik yang serupa yang menjadi pusat perhatian seorang peneliti karena itu dipandang sebagai sebuah semesta penelitian (Ferdinand, 2006). Populasi dalam penelitian ini adalah seluruh konsumen yang mengikuti program kursus di DEC pada bulan juli - agustus 2016 jumlahnya 120 peserta. Jumlah sampel menggunakan rumus dari Slovin dengan tingkat kesalahan 5\% didapatkan hasil penghitungan sebesar 92 responden.

\section{Teknik Pengambilan Sampel}

Menurut Sugiyono (2011), sampel adalah bagian dari jumlah dan karakteristik yang dimiliki oleh populasi. Sample merupakan bagian yang berguna bagi tujuan penelitian 
populasi dan aspek-aspeknya. Teknik penarikan sampel dalam penelitian ini menggunakan non probability sampling, yaitu teknik yang tidak memberikan peluang atau kesempatan sama bagi setiap unsur atau anggota populasi untuk dipilih menjadi sampel. Jenis sampel ini tidak dipilih secara acak.

Teknik penentuan sampel yang digunakan adalah Purposive Sampling dimana penelitian ini tidak dilakukan pada seluruh populasi, tapi terfokus pada target. Purposive Sampling artinya bahwa pengambilan sampel terbatas pada jenis orang tertentu yang dapat memberikan informasi yang diinginkan (Sekaran, 2006). Batasan tersebut seperti : Konsumen yang pernah mengikuti kursus sebelumnya, Usia minimal 16 tahun dan maksimal 50 tahun serta Berdomisili dari luar daerah

\section{Definisi Operasional Variabel}

\begin{tabular}{|c|c|c|c|}
\hline Variabel & Keterangan & indikator & Sumber \\
\hline $\begin{array}{l}\text { Word of Mouth } \\
x 1\end{array}$ & $\begin{array}{l}\text { Merupakan sumber yang } \\
\text { lebih dapat dipercaya } \\
\text { atau dapat diandalkan } \\
\text { untuk memperkuat dan } \\
\text { meningkatkan fenomena } \\
\text { yang ada. }\end{array}$ & $\begin{array}{l}\text { - } \text { Membicarakan, } \\
\text { - } \text { Mempromosikan, } \\
\text { - Merekomendasikan, } \\
\text { - Menjual produk / merek kita } \\
\text { kepada pelanggan lain. }\end{array}$ & $\begin{array}{l}\text { Ronny dan Chie } \\
\text { Jeffry Sunandar } \\
(2007)\end{array}$ \\
\hline $\begin{array}{c}\text { Brand Image } \\
y 1\end{array}$ & $\begin{array}{l}\text { Pandangan konsumen } \\
\text { berdasarkan persepsi suatu } \\
\text { merek terhadap berbagai } \\
\text { kepuasan yang ditawarkan }\end{array}$ & $\begin{array}{ll}\text { - } & \text { Citra Pembuat } \\
\text { - } & \text { Citra produk } \\
\text { - } & \text { Citra pemakai }\end{array}$ & Simamora (2002) \\
\hline $\begin{array}{l}\text { Purchase Intention } \\
y^{2}\end{array}$ & $\begin{array}{l}\text { pilihan yang dilakukan } \\
\text { konsumen untuk membeli } \\
\text { merek tertentu dibandingkan } \\
\text { merek yang lain dalam } \\
\text { kategori produk yang sama }\end{array}$ & $\begin{array}{l}\text { Saya akan membeli produk/ } \\
\text { merek ini daripada merek } \\
\text { lain yang ada } \\
\text { Saya bersedia untuk mereko- } \\
\text { mendasikan orang lain untuk } \\
\text { membeli produk / merek ini } \\
\text { - Saya berniat untuk membeli } \\
\text { produk/ merek ini lagi di } \\
\text { masa depan }\end{array}$ & $\begin{array}{l}\text { Shukla, }(2010) \\
\text { dalam Jalilvand } \\
(2012)\end{array}$ \\
\hline
\end{tabular}

\section{Metode Pengumpulan Data}

Studi Pustaka

Studi pustaka merupakan pengumpulan data yang dilakukan dengan membaca bukubuku literatur, jurnal-jurnal, internet, majalah, dan penelitian terdahulu yang berkaitan dengan penelitian yang sedang dilakukan (Baskoro, 2011).

\section{Studi Lapangan}

1. Kuesioner

Dalam suatu penelitian ilmiah, metode pengumpulan data dimaksudkan untuk memperoleh bahan-bahan yang relevan, akurat, dan terpercaya (Indrianto dan Supomo, 2003). Dalam penelitian ini pengumpulan data menggunakan kuesioner atau dikenal juga dengan sebutan angket. Kuesioner merupakan teknik pengumpulan data yang dilakukan dengan cara memberi seperangkat pertanyaan tertulis kepada responden untuk diisi. Dalam 
kuesioner ini sendiri terbagi dalam beberapa halaman yang mewakili variabel yang ada. Pertanyaan yang terlampir dalam kuesioner ini akan mewakili tiap-tiap indikator variabel yang telah ditentukan. Pengukuran variabel sendiri akan dilakukan dengan skala Likert yang menggunakan metode scoring sebagai berikut:

\begin{tabular}{|l|l|l|l|l||}
\hline Sangat Setuju (SS) & & $=$ Diberi bobot / skor 5 & & \\
\hline Setuju (S) & & $=$ Diberi bobot / skor 4 & & \\
\hline Netral (N) & & $=$ Diberi bobot / skor 3 & & \\
\hline Tidak Setuju (TS) & & $=$ Diberi bobot / skor 2 & & \\
\hline $\begin{array}{l}\text { Sangat Tidak } \\
\text { Setuju (STS) }\end{array}$ & & $=$ Diberi bobot / skor 1 & & \\
\hline
\end{tabular}

Angka 1 menunjukkan bahwa responden tidak mendukung terhadap pertanyaan yang diberikan. Sedangakan angka 5 menunjukkan bahwa responden mendukung terhadap pertanyaan yang diberikan.

2. Wawancara

Metode ini dilakukan untuk mengetahi data-data sekunder seperti profil sekolah, gambaran umum sekolah dan daftar siswa. Selain dengan melakukan penyebaran kuesioner, data-data yang terkumpul juga berasal dari riset lapangan, dimana data dapat diperoleh dengan melakukan penelitian langsung untuk mendapatkan data.

\section{Instrumen Penelitian}

Instrumen penelitian menggunakan kuesioner dengan pertanyaan terbuka dan skala likert dari 1-5. Teknik analisis dengan menggunakan software SMARTPLS yang terdiri dari: evaluasi measurement (outer model), inner model dan uji hipotesa

\section{HASIL DAN PEMBAHASAN}

\section{Uji Validitas}

Uji validitas dilakukan dengan menggunakan evaluasi measurement (outer) model yaitu dengan menggunakan convergent validity (besarnya loading factor untuk masingmasing konstruk). Convergent validity dari measurement model dengan indikator refleksif dapat dilihat dari korelasi antara masing-masing skor indicator dengan skor konstruknya (Ghozali, 2006). 
Tabel 1. uji validitas instrument penelitian

\begin{tabular}{|c|c|c|c|c|c|}
\hline & $\begin{array}{c}\text { Original } \\
\text { Sample } \\
\text { (0) }\end{array}$ & $\begin{array}{l}\text { Sample } \\
\text { Mean (M) }\end{array}$ & $\begin{array}{c}\text { Standard } \\
\text { Deviation } \\
\text { (STDEV) }\end{array}$ & $\begin{array}{c}T \\
\text { Statistics } \\
(\mid \mathrm{O} / \\
\text { STDEV|) }\end{array}$ & P Values \\
\hline $\mathrm{x} 1.1<-$ Word Of Mouth & 0.705 & 0.692 & 0.087 & 8.142 & 0.000 \\
\hline x1.2 <- Word Of Mouth & 0.557 & 0.543 & 0.145 & 3.833 & 0.000 \\
\hline $\mathrm{x} 1.3<-$ Word Of Mouth & 0.716 & 0.727 & 0.072 & 9.917 & 0.000 \\
\hline x1.4 <- Word Of Mouth & 0.589 & 0.555 & 0.155 & 3.794 & 0.000 \\
\hline y1.1 <- Brand Image & 0.488 & 0.436 & 0.258 & 1.891 & 0.059 \\
\hline y1.2 <- Brand Image & 0.733 & 0.735 & 0.104 & 7.071 & 0.000 \\
\hline y1.3 <- Brand Image & 0.740 & 0.726 & 0.110 & 6.701 & 0.000 \\
\hline $\begin{array}{l}\text { y2.1<- Purchase } \\
\text { Intention }\end{array}$ & 0.611 & 0.595 & 0.128 & 4.763 & 0.000 \\
\hline $\begin{array}{l}\text { y2.2 <- Purchase } \\
\text { Intention }\end{array}$ & 0.811 & 0.811 & 0.060 & 13.517 & 0.000 \\
\hline $\begin{array}{l}\text { y2.3<- Purchase } \\
\text { Intention }\end{array}$ & 0.712 & 0.697 & 0.107 & 6.685 & 0.000 \\
\hline
\end{tabular}

Sumber : data diolah, 2016

Seluruh pertanyaan (10 indikator) dalam kuesioner yang digunakan untuk mengukur variabel Word Of Mouth (X1), Brand Image (Y1) dan Purchase Intention (Y2) mampu untuk mengungkapkan sesuatu yang akan diukur oleh kuesioner tersebut, kecuali indicator $\mathrm{x} 1.2$, x1.4, y1.1, dan y2.1 yang hanya memiliki korelasi dibawah 0,7 (tidak valid) sehingga agar diperoleh model fit maka indikator yang tidak valid harus didrop dari model. Setelah mengeliminasi konstruk yang bernilai rendah maka diperoleh nilai Original sample estimate atau loading factor beserta nilai t-statistik dari indikator-indikator semua variabel.

\section{Uji Reliabilitas}

Uji reliabitas dilakukan dengan melihat nilai composite reliability yang dihasilkan dengan perhitungan PLS untuk masing-masing konstruk. Nilai suatu konstruk dikatakan reliabel jika memberikan nilai composite reliability $>0,70$ (Werts et al. 1979 dalam Ghozali, 2006). Hasil uji reliabilitas semua konstruk atau variabel penelitian ini sudah menunjukkan sebagai pengukuran yang fit, hal ini berarti bahwa semua item pertanyaan yang digunakan untuk mengukur masing-masing konstruk adalah reliabel. Nilai composite reliability masingmasing konstruk sangat baik di atas 0.70 .

Tabel 2. Hasil Uji Reliabilitas

\begin{tabular}{|l|l|l|l|l|}
\hline NO & \multicolumn{1}{|c|}{ KONSTRUK } & $\begin{array}{c}\text { COMPOSITE } \\
\text { RELIABILITY }\end{array}$ & \multicolumn{1}{|c|}{ AVE } & KETERANGAN \\
\hline 1 & Word Of Mouth & 0,776 & 0,634 & Reliable \\
\hline 2 & Brand Image & 0,746 & 0,595 & Reliable \\
\hline 3 & Purchase Intention & 0,792 & 0,660 & Reliable \\
\hline
\end{tabular}

Sumber : data diolah, 2016 


\section{Analisis Data}

Metode analisis utama dalam penelitian ini dilakukan dengan Structural Equation Model (SEM). Pengujian dilakukan dengan bantuan program SmartPLS. Teknik pengolahan data dengan menggunakan metode SEM berbasis Partial Least Square (PLS) memerlukan 2 tahap untuk menilai Fit Model dari sebuah model penelitian. Tahap-tahap tersebut adalah sebagai berikut :

\section{Menilai Outer Model atau Measurement Model}

Di dalam teknik analisis data dengan menggunakan SmartPLS ada tiga criteria untuk menilai outer model yaitu Convergent Validity, Discriminant Validity dan Composite Reliability. Convergent validity dari model pengukuran dengan refleksif indikator dinilai berdasarkan korelasi antara item score/component score yang diestimasi dengan Soflware PLS. Ukuran refleksif individual dikatakan tinggi jika berkorelasi lebih dari 0,70 dengan konstruk yang diukur.

Outer model atau measurement model dalam penelitian ini terdiri dari variabel Word Of Mouth (X1), Brand Image (Y1) dan Purchase Intention (Y2) yang dijelaskan oleh masing-masing indikator menunjukkan hasil uji outer loading dapat dikatakan memenuhi syarat yang dianjurkan kecuali indicator X1.2, X1.4, Y1.1 dan Y2.1 yang mempunyai nilai loading faktor kurang dari 0,7 , maka nilai outer loading belum dapat dikatakan memenuhi syarat yang dianjurkan sehingga indicator tersebut harus di drop dan dilakukan revisi model. Setelah dilakukan eliminasi terhadap outer model tersebut dan semua nilai outer loading sudah berada pada nilai yang dianjurkan $>0,70$, maka hasil tersebut dapat disimpulkan bahwa semua variabel sudah memenuhi syarat dari kecukupan model atau Discriminant Validity.

\section{Pengujian Model Struktural (Inner Model)}

Pengujian inner model atau model struktural dilakukan untuk melihat hubungan antara variabel, nilai signifikansi dan R-square dari model penelitian. Penilaian model dengan PLS dimulai dengan melihat R-square untuk setiap variabel laten dependen. Perubahan nilai R-square dapat digunakan untuk menilai pengaruh variabel laten independen tertentu terhadap variabel laten dependen apakah mempunyai pengaruh yang substantif. Tabel berikut ini merupakan hasil estimasi R-square dengan menggunakan SmartPLS.

Tabel 3. Hasil R-square

\begin{tabular}{|l|r|}
\hline & R Square \\
\hline Brand Image & 0.427 \\
\hline Purchase Intention & 0.280 \\
\hline
\end{tabular}

Sumber : data diolah, 2016

ini menunjukkan nilai R-square konstruk Brand Image sebesar 0,427 dan konstruk Purchase Intention sebesar 0,280. Semakin tinggi nilai R-square, maka semakin besar kemampuan variabel independen tersebut dapat menjelaskan variabel dependen sehingga semakin baik persamaan struktural. Untuk variabel Brand Image memiliki nilai R-square 
sebesar 0,427 yang berarti 42,7\% variance Word Of Mouth mampu dijelaskan oleh variabel Brand Image sedangkan sisanya dijelaskan oleh variabel lain di luar model penelitian. Variabel Purchase Intention memiliki nilai R-square sebesar 0,280 yang berarti 28\% variance Word Of Mouth dan Brand Image mampu dijelaskan oleh variabel Purchase Intention sedangkan sisanya dijelaskan oleh variabel lain di luar model penelitian.

\section{Pengujian Structural Equation Model (SEM)}

Metode analisis utama dalam penelitian ini dilakukan dengan Structural Equation Model (SEM). Pengujian dilakukan dengan bantuan program SmartPLS. Hasil pengujian diperoleh sebagai berikut:

\section{Gambar 1. Model Standart Model}

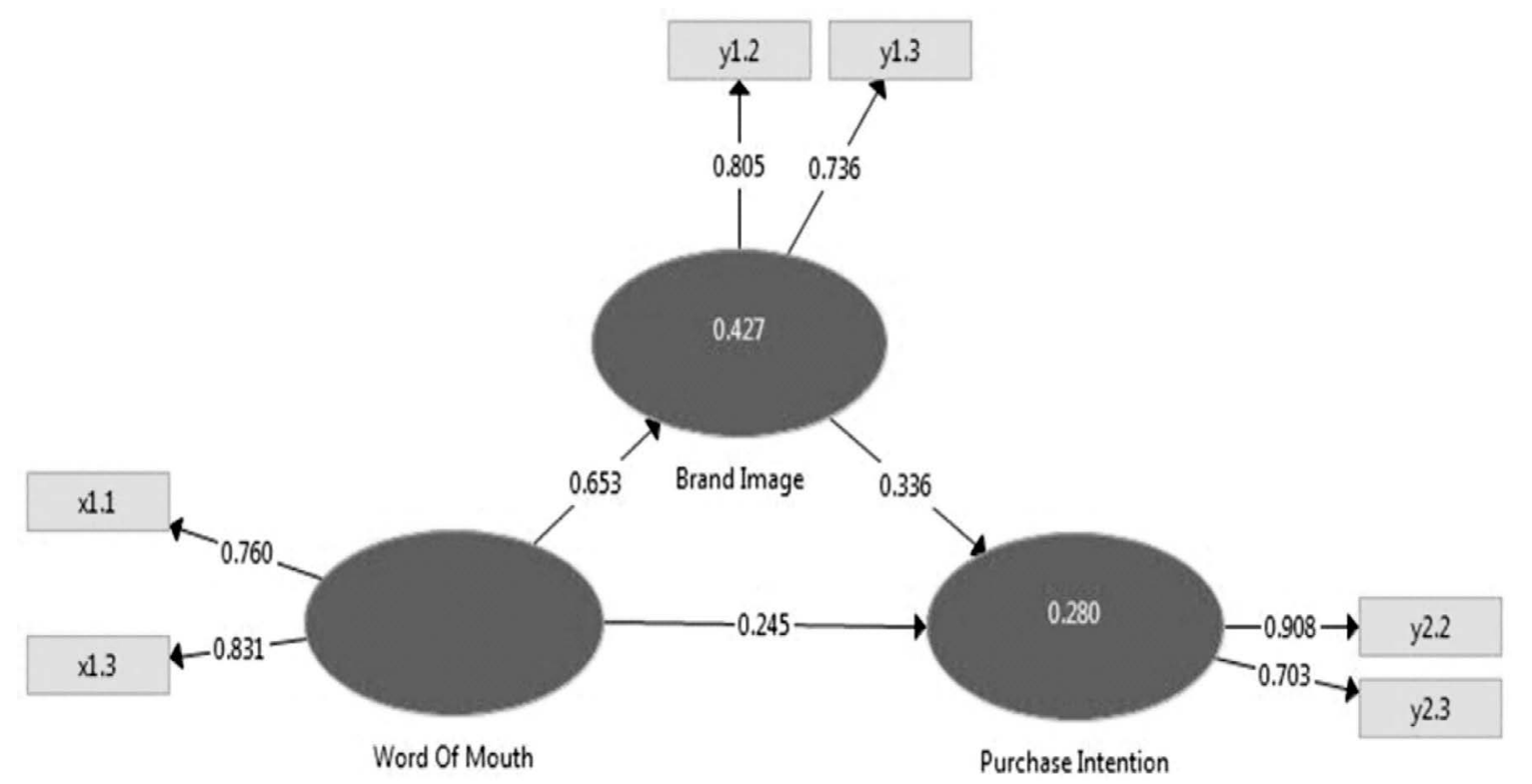

Sumber : Output SmartPLS, 2016

\section{Pengujian Hipotesis}

Pengujian hipotesis yang diajukan, dapat dilihat dari besarnya nilai T-statistik. Signifikansi parameter yang diestimasi memberikan informasi yang sangat berguna mengenai hubungan antara variabel-variabel penelitian. Batas untuk menolak dan menerima hipotesis yang diajukan adalah $\pm 1,96$, dimana apabila nilai t berada pada rentang nilai $-1,96$ dan 1,96 maka hipotesis akan ditolak atau dengan kata lain menerima hipotesis nol $\left(\mathrm{H}_{0}\right)$. Tabel 4 memberikan output estimasi untuk pengujian model struktural. 


\section{Gambar 2. Model Signifikan}

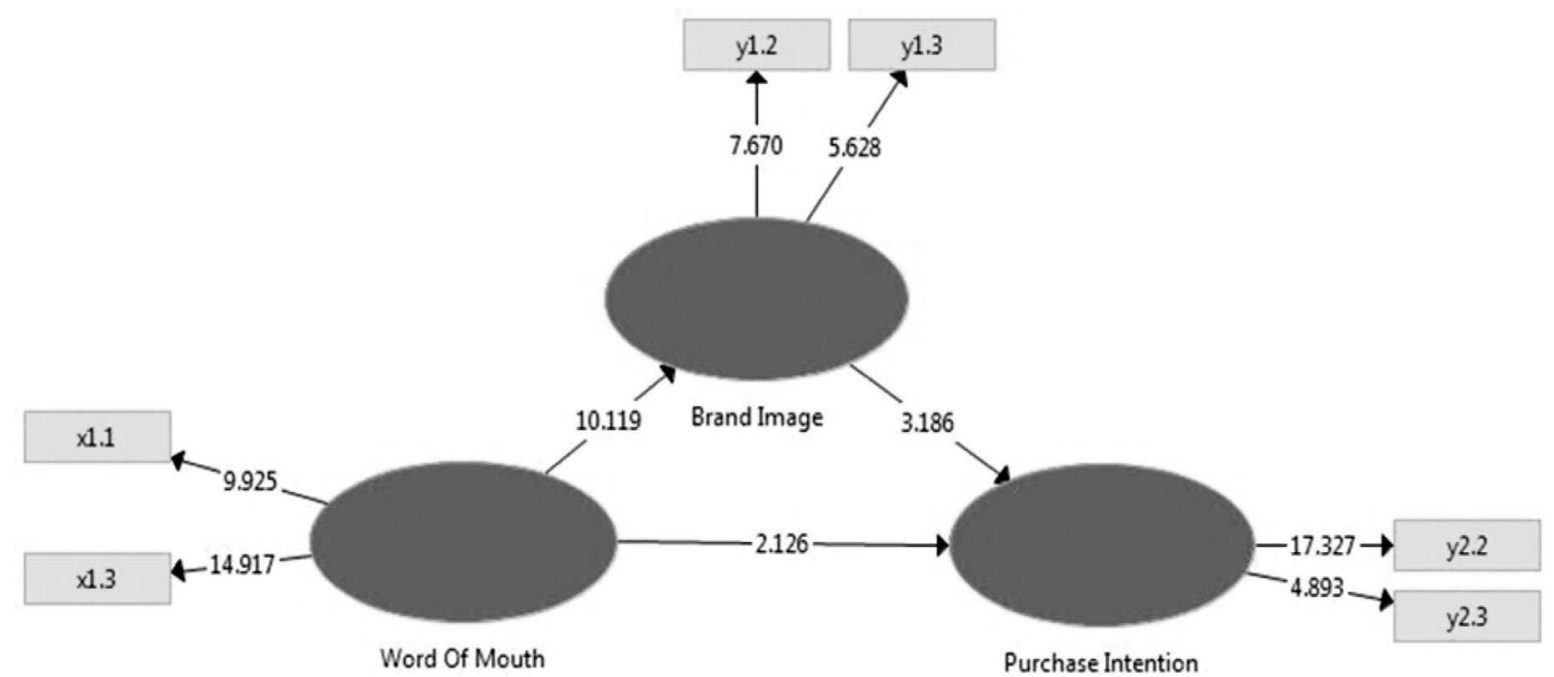

Dari gambar model signifikan tersebut dapat dibuat persamaan strukturalnya adalah sebagai berikut :

Brand Image $\quad=0.653$ Word Of mouth $+\zeta_{2}$

Purchase Intention $=0.245$ Word Of Mouth +0.336 Brand Image $+\zeta_{1}$

Tabel 4

RESULT FOR INNER WEIGHT

\begin{tabular}{|c|c|c|c|c|c|}
\hline Hipotesis & Variabel & $\begin{array}{l}\text { Original } \\
\text { Sample } \\
\text { Estimate }\end{array}$ & $\begin{array}{l}\text { Standard } \\
\text { Deviation }\end{array}$ & $\begin{array}{l}\text { T } \\
\text { Statistics }\end{array}$ & Kesimpulan \\
\hline H1 & Word Of Mouth $->$ Brand Image & 0.653 & 0.065 & 10.119 & Diterima \\
\hline $\mathrm{H} 2$ & $\begin{array}{l}\text { Word Of Mouth }->\text { Purchase } \\
\text { Intention }\end{array}$ & 0.245 & 0.115 & 2.126 & Diterima \\
\hline H3 & $\begin{array}{l}\text { Brand Image }->\text { Purchase } \\
\text { Intention }\end{array}$ & 0.336 & 0.105 & 3.186 & Diterima \\
\hline H4 & $\begin{array}{l}\text { Word Of Mouth } \rightarrow \text { Brand Image } \rightarrow \\
\text { Purchase Intention }\end{array}$ & 0.464 & 0.078 & 5.970 & Diterima \\
\hline
\end{tabular}

Sumber : Output SmartPLS, 2016 (Total Effect)

Tabel di atas menunjukkan bahwa pengaruh variabel WOM terhadap BI positif $(0,653)$ dan signifikan pada $\alpha=0,05$ dengan nilai statistic $10,119>1,96$. Pengaruh variabel WOM terhadap PI positif $(0,245)$ dan signifikan pada $\alpha=0,05$ dengan nilai statistic $2,126>$ 1,96. Pengaruh variabel BI terhadap PI positif $(0,336)$ dan signifikan pada $\alpha=0,05$ dengan nilai statistic $3,185>1,96$. Pengaruh variabel WOM terhadap PI melalui BI positif $(0,464)$ dan signifikan pada $\alpha=0,05$ dengan nilai statistic 5,970 $>1,96$. 


\section{Pengujian Hipotesis H1}

Hipotesis $\mathrm{H} 1$ menyatakan bahwa Word Of Mouth (WOM) berpengaruh terhadap Brand Image (BI). Hasil uji terhadap koefisien parameter antara WOM terhadap BI menunjukkan adanya pengaruh yang positif sebesar 0,653 (berdasarkan nilai Original Sample Estimate WOM -> BI pada nilai 0,653) dengan nilai T statistic sebesar 10,119 dan signifikan pada $\alpha=0,05$. Nilai $\mathrm{T}$ statistic tersebut jauh di atas nilai kritis 1,96 , dengan demikian hipotesis pertama dapat diterima.

\section{Pengujian Hipotesis $\mathbf{H 2}$}

Hipotesis H2 menyatakan bahwa Word Of Mouth (WOM) berpengaruh terhadap Purchase Intention (PI). Hasil uji terhadap koefisien parameter antara WOM terhadap PI menunjukkan adanya pengaruh positif sebesar 0,245 (berdasarkan nilai Original Sample Estimate WOM -> PI pada nilai 0,245) dengan nilai T statistic sebesar 2,126 dan signifikan pada $\alpha=0,05$. Nilai T nya jauh di atas nilai kritis 1,96 , dengan demikian hipotesis kedua diterima.

\section{Pengujian Hipotesis H3}

Hipotesis H3 menyatakan bahwa Brand Image (BI) berpengaruh terhadap Purchase Intention (PI). Hasil uji terhadap koefisien parameter antara BI terhadap PI menunjukkan adanya pengaruh positif sebesar 0,336 (berdasarkan nilai Original Sample Estimate WOM -> PI pada nilai 0,336 ) dengan nilai T statistic sebesar 3,186 dan signifikan pada $\alpha=0,05$. Nilai T nya jauh di atas nilai kritis 1,96 , dengan demikian hipotesis ketiga diterima.

\section{Pengujian Hipotesis H4}

Hipotesis H4 menyatakan bahwa Word Of Mouth (WOM) berpengaruh terhadap Purchase Intention (PI) Melalui Brand Image (BI). Hasil uji terhadap koefisien parameter antara WOM terhadap PI melalui BI menunjukkan adanya pengaruh positif sebesar 0,464 (berdasarkan nilai Original Sample Estimate WOM -> PI pada nilai 0,464) dengan nilai T statistic sebesar 5,970 dan signifikan pada $\alpha=0,05$. Nilai T nya jauh di atas nilai kritis 1,96 , dengan demikian hipotesis keempat diterima.

\section{Pembahasan}

Tabel 5. Direct, indirect dan Total Effect

\begin{tabular}{|c|c|c|c|c|}
\hline Pengaruh Variabel & Langsung & $\begin{array}{c}\text { Melalui Brand } \\
\text { Image }\end{array}$ & Total & Keterangan \\
\hline $\begin{array}{c}\text { Word Of Mouth -> } \\
\text { Purchase Intention }\end{array}$ & 0.245 & 0.219 & 0.464 & $\begin{array}{c}\text { Mediasi } \\
\text { sempurna }\end{array}$ \\
\hline $\begin{array}{c}\text { Brand Image -> Purchase } \\
\text { Intention }\end{array}$ & 0.336 & 0 & 0.336 & 0.653 \\
\hline $\begin{array}{c}\text { Word Of Mouth -> Brand } \\
\text { Image }\end{array}$ & 0.653 & 0 & \\
\hline
\end{tabular}

Sumber : data diolah, 2016 
Hasil analisis jalur menunjukkan bahwa Word Of Mouth (X1) secara langsung mempengaruhi Purchase Intention sebesar 24,5\% dan mempengaruhi secara tidak langsung, yaitu dimediasi oleh Brand Image sebesar 21,9\% dan total pengaruh Word Of Mouth terhadap Purchase Intention menjadi 46,4\%. Oleh karena adanya kenaikan pengaruh dari yang semula 24,5\% menjadi 46,4\% maka Brand Image dapat dikatakan memediasi secara sempurna.

\section{KESIMPULAN}

1) Word-of-Mouth berpengaruh positif terhadap Brand Image. Hal ini menunjukkan bahwa semakin konsumen menganggap Word-of-Mouth baik, maka akan menyebabkan tingkat penilaian terhadap Brand Image yang semakin tinggi. Word-of-Mouth pada konsumen berada dalam kategori cukup baik. Berdasarkan rekapitulasi jawaban responden masih terdapat indikator yang tidak mencapai rata-rata nilai, mempromosikan dan menjual produk / merek kepada pelanggan lain.

2) Word Of Mouth berpengaruh positif terhadap Purchase Intention. Hal ini menunjukkan bahwa semakin baik Word Of Mouth, maka semakin baik respon peserta didik terhadap Purchase Intention meskipun peserta didik minim pengetahuan tentang citra manajemen.

3) Brand Image berpengaruh positif terhadap Purchase Intention. Ini menunjukkan bahwa semakin baik Brand Image dari DEC maka semakin baik pula respon peserta didik terhadap Purchase Intention meskipun ada sedikit peserta didik yang enggan mencoba kembali karena ingin mencoba di tempat lain.

4) Antara Word Of Mouth dengan Purchase Intention terdapat pengaruh mediasi dari Brand Image. Hal ini ditunjukkan oleh peningkatan pengaruh Purchase Intention yang lebih besar ketika Melalui Brand Image daripada pengaruh Word Of Mouth langsung ke Purchase Intention. Peserta didik merasa lebih yakin dalam memilih kursus di DEC ketika mereka tidak hanya mendengar tetapi juga ditunjukkan citra DEC yang sudah terbukti mampu mencetak pribadi yang cakap dalam kemampuan berbahasa inggris.

\section{Saran}

1) Perlu adanya inovasi baru dalam bentuk kegiatan pembelajaran agar dapat dilirik oleh peminat kursus yang baru maupun lama.

2) Lebih memaksimalkan e-commerce karena saat ini hampir semua mengenal digital marketing.

\section{DAFTAR PUSTAKA}

Dana Fitriana dan Ida Yulianti JIM FEB UB Malang Vol. 2 No. 2 Tahun 2013 "Pengaruh Brand Image Terhadap Purchase Intention Pada Produk Otomotif (Studi Kasus Pada Calon Pembeli Toyota Avanza Di Auto 2000 Sutoyo- Malang )".

Hasan, Ali. 2011. Marketing dari Mulut ke Mulut (Word of Mouth). Yogyakarta: Media Press Hurriyati, Ratih, Dr., M.Si. "Bauran Pemasaran dan Purchase Intention". 2010. Jakarta: Alfabeta CV 
Kotler, \& Amstrong. 2001. Dasar-dasar Pemasaran. Edisi kesembilan. Jakarta: Indeks

Kotler \& Keller. 2007. Manajemen Pemasaran. Edisi 12. Jilid 1 \& 2. Jakarta: Indeks

Kotler, Philip. 1994. Manajemen Pemasaran, Analisis, perencanaan, implementasi, dan pengendalian. Jilid 1. Jakarta: Erlangga

Lathifah, Ifah. Magister Manajemen Universitas Diponegoro Semarang 2008 "Pengaruh Konflik Pekerjaan-Keluarga Terhadap Turnover Intentions Dengan Kepuasan Kerja Sebagai Variabel Intervening (Studi Empiris Pada Auditor Kantor Akuntan Publik Di Indonesia)"

M. Yudha Ghozali dan Tommy Setiawan Ruslim. Fakultas Ekonomi Universitas Tarumanegara, Jakarta, Indonesia. Tahun 2015 "Efek E-WOM terhadap Brand image dan Purchase Intention (Studi Kasus Pada Industri Mobil “D”)".

Tjiptono, Fandy. 1997. Strategi Pemasaran. Edisi 1. Yogyakarta: Andi

--. 2005. Brand Management \& Strategy. Yogyakarta: Andi Offset

2008. Strategi Pemasaran. Edisi Ketiga. Yogyakarta: Andi 